\title{
INTERNAL LABOR MARKETS UNDER EXTERNAL MARKET PRESSURES
}

\begin{abstract}
JEONG-YEON LEE*
Through an empirical investigation of 11 Korean firms before and after the Asian financial crisis, the author examines the impact of increasing external market pressures on internal labor market (ILM) practices. In addition, the merits of ILMs are tested by capturing the reactions of white-collar managers within these firms. The author posits that 1) firms may desert ILM practices in the face of external pressures but do so in varying degrees, and 2) despite reduced values placed on firm-specific human capital in the marketplace, ILM practices continue to have merit in promoting consummate cooperation and delaying perfunctory cooperation. The findings generally support the hypotheses, and implications of these results for theory and practice are discussed.
\end{abstract}

$\mathrm{S}_{\mathrm{in}}^{\mathrm{in}}$ ince Doeringer and Piore's (1971) seminal work, many labor economists and organization theorists have researched factors that give rise to the attributes of internal labor markets (ILMs) (Pfeffer and Cohen 1984). Economists have interpreted ILMs as a joint investment between employer and employees in firm-specific skills (Doeringer and Piore 1971), focusing their attention on the incentive aspects of ILM practices. Sociologists, institutional economists, and organizational theorists, by contrast, have paid attention to the institutional characteristics of ILMs. That is, organizations often bureaucratize employment relations rather than rely on the external labor market because it cannot always provide the skills that the firm needs (Ouchi 1980; Adler and Borys 1996). Such bureaucratization involves developing and practicing internal standards for hiring, training, promoting, and rewarding employees, thereby creating an internal labor market. ILMs are a constellation of these firm practices that promote the accumulation of firm-specific human capital. They typically include the following features: seniority-based rewards (Doeringer and Piore 1971; Gerhart and Rynes 2003; Dulebohn and Werling 2007), long-term employment (Doeringer and Piore 1971; Gerhart and Rynes 2003), on-the-job training (Doeringer and Piore 1971; Pfeffer and Cohen 1984; Gerhart and Rynes 2003), and promotion from within (Althauser and Kalleberg 1981).

"Jeong-Yeon Lee is Associate Professor at the University of Kansas, School of Business. I thank Denny Organ, Phil Podsakoff, Janet Near, George Dreher, Laura Poppo, Diane Burton, and Tailan Chi for their helpful comments on earlier drafts of the manuscript. Jim Guthrie was tremendously helpful with the final version. A data appendix with additional results, and copies of computer programs used to generate the results presented in the article, are available at jaylee@ku.edu.

KEYWORDS: internal labor markets, firm-specific human capital, consummate cooperation

ILR Review, 68(2), March 2015, pp. 338-371

DOI: $10.1177 / 0019793914564964$. (C) The Author(s) 2014

Journal website: ilr.sagepub.com

Reprints and permissions: sagepub.com/journalsPermissions.nav 
One of the clearest patterns in the contemporary employment relationship in the Western world, and increasingly in other nations that have opted for full participation in the global economy, is the disintegration of ILMs in the face of external market pressures (Abraham 1990; Cappelli 1995; Horan 2004). Global competition and restructuring and external shocks such as the financial crisis in Asia and the global recession of the early 2000s exacerbated this process (Osterman 2008). According to Royal and Althauser (2003), market-based arrangements once dominant in the 1800s and 1900s (Jacoby 1984) have apparently returned. Royal and Althauser even argued that the theory of internal labor markets is "now questionable" (2003: 26) and that the benefits of ILM theory might have been overstated. Others have called for further research to fully investigate the efficacy of ILMs in a changing world (Osterman and Burton 2004).

The competitive and volatile global environment indeed challenges the logic of ILM theory but at the same time opens up a research opportunity. Given this context, I address two important research questions. First, to what extent have firms changed their ILM practices in response to changes in external markets? Particularly, have they responded in a uniform pattern or in varying degrees? Although previous research has qualitatively described the disintegration of ILMs, few studies have attempted to measure the extent of change or to address which firms may differ in retaining or deserting ILM practices when they face the same level of external pressures or shocks. Second, when firms retain ILM practices, what do ILMs mean to employees, particularly managers whose employment relationships are in transition? Specifically, given the increasing challenge of market-based arrangements to internal labor markets, how do employees react to a firm's retention of ILM practices?

The current study examines the possibility that although the once-prevalent practices of ILMs may be disappearing as a result of external pressures, these practices continue to have merit by encouraging employees to remain committed to the firm and delaying the onset of what is termed perfunctory cooperation (Williamson, Wachter, and Harris 1975) — that is, instrumental behavior.

\section{Background and Theoretical Development}

ILM theory has never commanded a perfect consensus among scholars regarding the prevalence or merits of adopting these practices. One apparent pattern observed in the global economy, however, is the soaring level of external pressures that discourage the use of ILMs. In Western economies, these pressures include the rise in part-time work (Abraham and Taylor 1996; Segal and Sullivan 1997); the considerable decline in job security (Batt 1996; Gordon 1996; Smith 1997; Aaronson and Sullivan 1998; Schmidt 1999); and the increase in the use of restructuring, outsourcing, and downsizing due to heightened global competition (Osterman 2000, 2008; Friedman 2005). In Asia, such as in Japan and Korea, research shows that job security and lifetime employment practices are also breaking down (Kuwahara 2010; Park and Legget 2010). Criticism of seniority-based rewards has risen along with an increase in the use of part-time workers. 
Often external market pressures come as a sudden external shock in a time of economic crisis. The Korean economy, which experienced such a shock shortly after the 1997 Asian financial crisis, serves as the empirical context of this study. The crisis led to direct pressure by the International Monetary Fund program on Korean firms to reform and restructure operations so that resources could be more quickly and efficaciously reallocated in response to signals from the external economy. As a result, Korean manufacturing firms began the process of structural and managerial reforms that would considerably decrease the extent to which they relied on ILMs (see the details in Kim and Kim 2003). Despite similar trends in many national economies, a systemic description of institutional changes in retaining or deserting ILMs in a time of crisis and subsequent consequences has not been a subject of scrutiny in the scholarly literature. It is important to understand how firms made choices in terms of retaining or deserting ILMs in response to changes in external markets. It is not clear, for example, whether they uniformly gave in to external pressures or whether there were varying degrees of retention. Additionally, it is important to examine the consequences of varying choices.

The existing ILM literature is somewhat limited in providing answers to these questions because the majority of studies have focused on the evolutionary process of how and why firms adopted ILMs. Thus, ILMs are treated mostly as an optimal outcome rather than as predictors of relevant firm outcomes. Most studies have investigated what leads to the use of ILMs or whether employees are indeed compensated according to ILM principles (Pfeffer and Cohen 1984; Sheets and Ting 1988; Davis-Blake and Uzzi 1993). Institutional economists and industrial relations scholars have focused on the historical context and role of institutions in shaping the ILM phenomenon (Jacoby 1984, 2004) (Kanter 1984; Ryan 1984). The studies have viewed ILMs as rational cooperative systems among employers and employees (Jacoby 2004) and have focused mainly on the existence and confirmation of the ILM phenomenon.

The evolutionary perspective has contributed to our understanding of why ILMs emerged in the first place, but given the abundant research on ILM evolution and the ever-growing external pressures on ILMs, it is time to shift the focus of research. Instead, it may be more useful to investigate how employers reorganize their ILM practices in the face of external market pressures, and how employees in turn respond to employer actions. In investigating employee responses, the current study focuses on white-collar managers ${ }^{1}$ to help reduce

\footnotetext{
${ }^{1}$ Osterman (1987) suggested that different ILM systems may exist depending on different occupational groups. Specifically, he identified four different ILM subsystems within firms: industrial, salaried, craft, and secondary. Although most of the economics and industrial relations research has emphasized blue-collar workers, a group in which the industrial subsystem is most often used, the current research focuses on the salaried model for white-collar managers, which is considered to have more flexible administrative procedures and greater commitment to employment security. According to Kanter (1993), clearly defined job ladders and promotion sequences, which are the major traits in the industrial subsystem, are often absent in the salaried model. Ryan (1984) also pointed out that transferable general skills may be more important for managers. Because of this variation in ILMs across occupations, I chose to focus on only one occupational group-white-collar managers. In addition, before the Asian financial crisis, white-collar managers in Korea (the sample of the current study) were characterized as having much more rigid external job mobility and less flexible administrative procedures than managers in the United States (Jung and Cheon 2006).
} 
"noise" and isolate the phenomena of interest. Because ILMs can be both a firm-specific and an occupation-specific phenomenon (Osterman 1987), holding the occupation constant (i.e., to white-collar managers) allows me to focus on variation in ILMs among firms rather than among occupations.

\section{External Pressures and Firm Choices in the Use of ILMs}

In response to external pressures, firms may desert ILM practices entirely. In this case, we would observe a similar decline in the use of ILM practices across all firms. For example, national data show an overall decline in organizational tenure and wage premiums on tenure, suggesting that firms have substantially reduced ILM practices in the face of external market pressures over the last two decades (Chauvin 1994; Osterman 2008). What is less clear is how firms may vary in conceding to such pressures.

Ironically, the globalization of labor markets may increase the variation in ILM attributes across firms. On the one hand, many firms may have become skeptical about the viability of ILM practices. Global pressures to compete on innovation and time to market have placed a premium on flexibility and adaptability. Also, global competition exerts pressure on firms to contain or reduce costs, including those of labor, and changes in markets and technology render many forms of skill and knowledge superfluous, outdated, or suddenly overpriced in the context of internal labor markets, as in Osterman's (2008) example of IBM. In these conditions, leaders may be less likely to feel the need to retain the high level of cooperation from employees that is developed through ILMs, and they may be loath to commit even implicitly to long-term relationships with subordinates. Instead, they are likely to concentrate resources on the acquisition of cooperation based on highly specialized expertise that commands a premium in the global external labor market. As a result, some firms will consider employment security a vestige of a time long past (e.g., Cappelli 1999).

On the other hand, some firms may have rediscovered the value of longterm cooperation and may even see it as essential for organizational survival under the globalization of labor markets. Having found that procurement of such cooperation is not easy when employment relationships are externalized, these firms may decide to adhere to ILM principles. For example, despite external pressures, some authors (e.g., Pfeffer 2010) advocated no-layoff promises and long-term employment (i.e., employment security), which is one of the major features of ILMs (Doeringer and Piore 1971; Gerhart and Rynes 2003). Thus, globalization may induce firms to reshape their channels of organizing employment relations to either retain or desert ILM attributes, resulting in a variety of overall ILM practices among firms. In an economy shaped by external market pressures and globalization, I propose the following:

Proposition 1: The extent to which ILMs are employed by firms will decrease under external market pressures, but the extent to which ILM employment varies among firms will increase. 


\section{Consummate vs. Perfunctory Cooperation as Reactions to ILMs}

The current era of the globalization of markets (including labor markets: Friedman 2005) provides a context for a more stringent test of ILM efficiency. I argue that while the prevalence of internal labor markets may have declined, their merits have not. The widened variation in the use of ILMs across firms may create a situation in which employees are more sensitive and responsive to the existence of ILM practices and the benefits they provide. In other words, the incentive effects of internal labor markets on employee behavior are likely to be more pronounced as employees compare their own employment conditions with those of others. Support for the ILM hypothesis (and its association with cooperative employee behavior as explained below) can be found more often in an economy that has variation in the use of ILMs due to the external market pressures than in one for which ILMs are the norm (as in the Korean Chaebols before the Asian financial crisis). Thus, I am likely to observe a strong relationship between variation in ILMs and employee cooperative behavior.

In examining the merits of ILMs, I focus on employee cooperation because the real benefits and limitations of internal labor markets can best be observed through their impact on employee behavior. In particular, in the advent of external market pressures, the extent to which employees are willing to cooperate with firm objectives may be at risk. Williamson et al. (1975) distinguished between "consummate cooperation" (genuine or authentic cooperation) and "perfunctory cooperation" (cooperation only to the extent that it is sufficient to avoid censure, reprimand, or termination). Consummate cooperation has much in common with the concept of "organizational citizenship behavior" (OCB; Organ, Podsakoff, and MacKenzie 2006) but with the qualification that OCB draws upon job-relevant knowledge, including firm-specific and task-specific skills. Consummate cooperation implies a level of application of firm-specific skills that goes beyond the most literal or enforceable terms of the job description; it implies some degree of initiative or proactive behavior; and it is carried out without regard to mechanisms for metering the employee's contributions. This type of cooperation is often important when workers need to combine efforts for a single outcome (Ouchi 1980). Jensen and Meckling's (1976) term "cooperative efforts" described this well. As noted by Williamson et al. (1975):

Consummate cooperation is an affirmative job attitude-to include the use of judgment, filling gaps, and taking initiative in an instrumental way. Perfunctory cooperation, by contrast, involves job performance of a minimally acceptable sort. Incumbents, who through experience have acquired task-specific skills, need merely to maintain a slight margin over the best available inexperienced candidate. . . . The upshot is that workers, by shifting to a perfunctory performance mode, are in a position to "destroy" idiosyncratic efficiency gains. (Williamson et al. 1975: 266)

The problem for organizations short on consummate cooperation is that while employees do what is minimally required, they may not cooperate in a 
way that fully utilizes their accumulated firm-specific skills and knowledge on the job. For instance, employees within an internal hierarchy acquire job-relevant knowledge (i.e., understanding the personality of team members, internal procedures for how the job is done, and unique technology pertinent for firm production) that may or may not be used for the benefit of others in the firm and for the firm itself. Only when employees use their knowledge to help others, share the knowledge, and take the initiative to improve work procedures may it be said that they are cooperating consummately as opposed to perfunctorily. According to Williamson et al. (1975), this kind of consummate cooperation, characterized as high asset-specificity, cannot be obtained by hiring from external labor markets. Accordingly, it is consummate cooperation that may be at risk when ILMs are under external market pressures. Therefore, revisiting the effects of ILMs on consummate cooperation is an important research endeavor. When we do so, a primary question arises. Under external market pressures, do ILMs still induce more cooperation while delaying the diminishing level of cooperation that originates from accumulated firm-specific human capital?

\section{Firm-Specific Human Capital and Consummate Cooperation}

I have argued that ILMs provide incentives to increase consummate cooperation and that variation in ILM practices across firms will be associated with variation in the level of consummate cooperation of employees across firms. ILM theory also addresses the issue of variation in the level of consummate cooperation of employees within firms. According to Williamson et al. (1975), as employees acquire more firm-specific human capital, they may not use their firm-specific knowledge unless the proper incentives and monitoring are in place. That is because, unlike general knowledge and skills, the acquisition of firm-specific human capital creates information asymmetries, or what Williamson et al. (1975) call "information impactedness" between employees and employers. The higher the level of employees' firm-specific skills, the less information employers have about those skills. This provides space for employees with higher firm-specific skills to engage in perfunctory cooperation compared to those with fewer firm-specific skills.

The effects of information impactedness are likely to increase when external market pressures are high because they enhance uncertainty and opportunism. Under conditions of uncertainty, employers have less knowledge of the relative utility of firm-specific skills and employees may have more incentives to increase opportunistic behavior.

Agency costs may also arise because of the divergent interests of employers (i.e., principals) and employees (i.e., agents) and information asymmetry associated with firm-specific human capital. That is, employees know best how to utilize their firm-specific human capital, whereas employers have limited knowledge. But more important, agency problems may be exacerbated because monitoring mechanisms (on firm-specific human capital and employee use of it) may have been degraded along with the 
depreciated value placed on firm-specific human capital under the influence of external market pressures.

An additional consideration is that employees who have a high level of firmspecific human capital may feel a sense of social and psychological breach if employers begin to view firm-specific skills as outdated and respond to external pressures by reducing their commitment to ILMs. Williamson et al. (1975) described how the adoption of market mechanisms hindered the preexisting voluntarism among blood donors in England. They suggested that the sudden external pressure or shock might have created a sense of social or psychological contract breaches (Rousseau and Parks 1992; Robinson, Kraatz, and Rousseau 1994; Robinson 1996) among employees. Osterman (2008) also described how external market pressures have led to a decline in loyalty among middle managers in the United States. Thus, when firms reduce their commitment to ILMs, those employees with a higher level of firm-specific capital, accumulated over many years, are likely to experience a higher level of contract breach, compared with employees with less accumulated tenure.

For these reasons, under heightened external market pressures, it is likely that, as firm-specific human capital increases, consummate cooperation will increase at a decreasing rate.

Hypothesis 1: There will be a curvilinear (inverted U) relationship between firm-specific human capital and consummate cooperation.

\section{Retention of ILMs and Consummate Cooperation}

Although the ILM literature has focused on how ILMs foster firm-specific skills, the increased information impactedness associated with firm-specific human capital under external market pressures suggests that being equipped with firm-specific human capital is not enough to ensure that employees cooperate fully in their use of their skills. Thus, they may adopt a more perfunctory mode of cooperation. As argued earlier, this pattern may be even more pronounced rather than eliminated in the face of external labor market pressures. As a result, a firm's decision to retain ILMs could lead to a higher level of consummate cooperation than would otherwise occur.

Several scholars have suggested that the monitoring and supervising function of ILMs can promote cooperation. Monitoring has both positive and negative aspects (Niehoff and Moorman 1993; Barney and Hesterly 1999). Negatively, it implies a management's lack of trust in its workers. But monitoring may also function as a safeguard to ensure that a fair appraisal of an employee's contribution can be made and a fair reward expected (Williamson et al. 1975). Therefore, in the long run, monitoring may raise employees' expectations that cooperation will be rewarded. It is this latter function of monitoring to which the ILM literature pays attention. In this work, I use the terms supervision and monitoring interchangeably and focus only on the positive side of monitoring and supervision. 
Alchian and Demsetz (1972) argued that supervision reduces the likelihood of diminution of effort and that a hierarchy emerges as individuals are assigned to supervising roles. Ouchi (1980) argued that to obtain employee cooperation, bureaucratization has two principal advantages over the market. First, it uses an incomplete contract, which allows organizations to appoint a supervisor to direct work activities and monitor employee performance in exchange for higher wages. The supervisor position is part of an internal hierarchy and is necessary for carrying out internal standards of hiring, promoting, and rewarding employees.

Second, supervisors understand the firm-specific context better. As a result, Ouchi (1980) believed that "the costs associated with ensuring fair transactions" (e.g., evaluating the value of cooperation, sorting out true cooperators, and administering fair compensation) will be smaller with supervisors. Since both employers and employees see the joint benefits of transaction cost savings (the costs otherwise carried by the two parties) in the form of reduced bargaining, monitoring, and maladaptation costs (Williamson 1985: 21), the use of ILMs will evoke employee cooperation. For the employee, the existence of these retained ILM attributes in a time of external market pressures can be interpreted as an employer's continued commitment to measure and compensate employee cooperation in a fair manner by using internal standards and rewarding cooperation through internal promotion.

Using the logic of transaction cost efficiency and an enhanced sense of fairness in transactions by "metering" (i.e., supervising-monitoring/measuring and providing fair incentives) consummate cooperation, Williamson and his colleagues (1975: 270) believed that ILMs will provide more incentives to "encourage employee cooperation." In addition, internal labor markets often provide an internal competition: positions are awarded to the winners-those who show greater contributions over the long term (Fairris 2004). Not only supervision but also internal competition and peer pressure can provide incentives for workers to engage in consummate cooperation. The merits of ILMs in terms of retaining consummate cooperation will be more apparent under conditions of heightened external market pressures because employees can more easily identify how the ILM practices in their firm differ from others.

In addition, retaining ILMs may also minimize psychological contract breaches (Rousseau and Parks 1992; Robinson et al. 1994; Robinson 1996). Between the two types of psychological contracts, transactional and relational (Robinson et al. 1994), it is the latter that ILMs may heavily influence. ILMs create relational contracts that involve "an open-ended, less specific agreement that establishes and maintains a relationship" (Robinson et al. 1994: 138) based on long-term commitments. I argue, quite contrary to many market advocates, that under external market pressures the role of relational psychological contracts in creating consummate cooperation can be even more important as the relational component of the psychological contract may become a scarce phenomenon. 
Hypothesis 2: There will be more consummate cooperation at the same level of firm-specific human capital in cases for which a firm relies more on ILM practices.

\section{ILMs as a Device to Delay Perfunctory Cooperation}

Another potentially important advantage of internal labor markets is their ability to reduce the advent of perfunctory cooperation as employees acquire more firm-specific human capital. Several studies point to the possibility that perfunctory behavior among more senior employees may be delayed in firms that retain some level of commitment to ILMs (compared to those that do not). Alchian and Demsetz (1972) have argued that a reduction of effort is not completely eliminated by hierarchy. Because monitoring involves costs, it makes sense to monitor only to the point at which the marginal benefits from reduced consummate cooperation equal the marginal costs of monitoring. A strong possibility exists that perfunctory cooperation can still occur and is simply delayed up to a point at which marginal costs do not exceed the marginal benefits of monitoring.

The point of perfunctory cooperation of this sort may be delayed to a higher level of firm-specific skill accumulation in firms with stronger ILMs. First, as employees become aware that ILMs meter additional consummate cooperation and rewards them through internal promotion, they may perceive significantly higher expectancies, particularly performance-outcome expectancy or instrumentality (Vroom 1964). The incentives encourage employees to continue to make extra efforts beyond the point at which they would otherwise have started to reduce consummate cooperation when such incentives are absent. Second, even though monitoring employees with high firm-specific skills is difficult in general, ILMs provide a better context to detect the reduction of consummate cooperation (Willamson et al. 1975). ILMs employ supervisors who have gone up the internal ladder and are considered to be in a better position to evaluate such quality (Jones 1984). Therefore, employees who would have reduced consummate cooperation in the absence of an ILM will have reasons to delay this tendency to a later point when there are fewer people with the ability to catch the desertion. Third, internal competition among job incumbents within the firm puts limitations on the early development of the incumbent's advantage (Malcomson 1984) as employees become aware that potential job replacements inside the company have a similar level of firm-specific skill and thus a similar advantage.

These advantages will still exist in retained ILMs in external market pressure. As argued in Hypothesis 1, employees with high firm-specific human capital are likely to reduce the rate at which they increase consummate cooperation if they know firm-specific human capital is not valued in the labor market. In addition, the sense of social contract/psychological contract may play a role for employees with substantial firm-specific human capital who have limited options to change employers. The more firms hang 
Figure 1. Hypothesized Relationship between Employee Firm-Specific Human Capital and Consummate Cooperation at Different Levels of ILM Strength

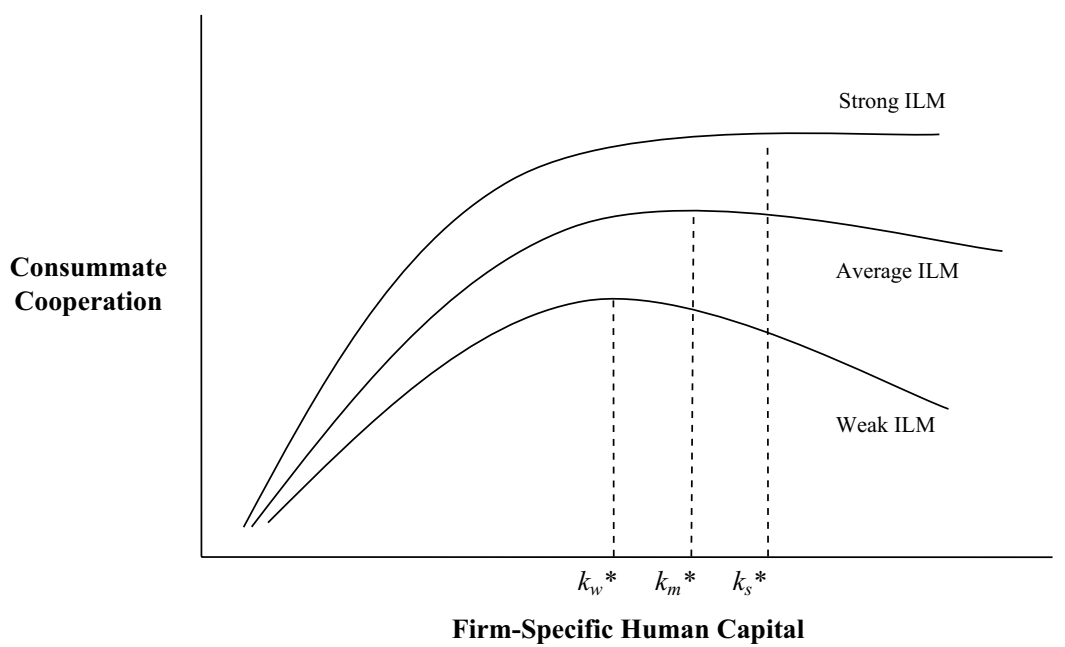

on to ILMs in this context, the more employees will be motivated to delay their perfunctory cooperation. Thus I generate the following hypothesis.

Hypothesis 3: For employees with the same level of firm-specific human capital, the point at which consummate cooperation tails off occurs later in firms with stronger ILMs compared to those with weaker ILMs.

The above hypothesis is depicted graphically in Figure 1. Where a firm relies more on ILM practices, the incentive and metering aspects of the ILM should encourage employees to continue to increase their cooperation beyond $k_{w}{ }^{*}$; but where these incentives and metering are lower, employees are likely to reduce their consummate cooperation at an earlier point, resulting in $k_{w}{ }^{*}<k_{s}^{*}$.

\section{Methods}

\section{Procedure}

To test my hypotheses, I needed a sample of firms that I had reason to believe had significant variation in their ILM practices and a sample of employees within those firms. Manufacturing firms in South Korea and white-collar managers working in those firms met these requirements. Several advantages to the sample choice are apparent. First, as the study focuses on employee cooperation in response to ILMs in conjunction with firmspecific human capital, one condition of my story is that firms first make decisions about the use of ILMs and then employees make decisions about their optimal amount of consummate cooperation given the level of their firm-specific human capital. This assumption is more likely to be true among large Korean firms because the Asian financial crisis first triggered Korean 
firms to reevaluate their use of ILMs; employees then had to adjust and respond to employers' choices. Additionally, even though the current study is not longitudinal, this setting allowed me to assume that the varying degrees of ILM practices in place following the Asian financial crisis were a response to the crisis, because prior research demonstrated that large Korean firms were quite homogenous in their adherence to ILM practices before the financial crisis (Jwa 2002; Chang 2003; Kim and Kim 2003; Evans 2007). Recall that my theoretical model of employee cooperation also assumes the exercise of employee discretion when firm-specific skill acquisition creates an agency issue. White-collar managers are more likely to have such discretion and also to have opportunities to engage in perfunctory cooperation because their jobs involve the accumulation of substantial amounts of firm-specific human capital.

I collaborated with six other professionals in economic research institutes affiliated with Korean industrial conglomerates. The strategy was to study major firms selected from the top 30 Chaebols (large conglomerates) in Korea in 1995 (Jwa 2002). Before the Asian financial crisis in 1997, these companies were heavily dependent on ILMs (Chang 2003; Evans 2007). I chose the five manufacturing industries most representative of the main businesses of these top 30 Chaebols. My sample includes two firms each from the automotive, chemical, electrical, and metal/plastics industries; and three firms from the electronics industry. Each of these firms employed more than a thousand people (both theory and research have suggested that number of employees to be a correlate of ILM characteristics [Baron, Davis-Blake, and Bielby 1986]).

Upon gaining access to each company, my six professional contacts selected teams so that I could obtain a number of respondents from functional areas in proportion to the distribution of the six areas (see details below) in a specific firm. Teams were selected using the random number generator in Excel. The names of all supervisors in the participating firms were entered into a spreadsheet. From this list, the researchers randomly selected team leaders who would ultimately identify participants for this study. After the supervisors were selected, the researchers delivered the surveys to participating firms. Supervisors were requested to distribute surveys to all team members or, when there were more than 15 members, to randomly identify a subset for participation (using the random selection procedure described above). Most of the surveys were delivered in person to the supervisors, but a small portion were sent by mail.

The envelopes that the supervisors received contained two survey formsone for the supervisor, the other for subordinates. The supervisor form contained items denoting the functional area and descriptive statements about the consummate cooperation of designated subordinates. Items on the subordinate forms elicited information pertaining to tenure and number of jobs held within the firm and demographic factors such as age, education, and marital status. Surveys were coded to permit matching data points. All survey instruments were developed in English but later formatted into Korean using 
the translation-back procedure (Sinaiko and Brislin 1973). A pilot test employing these measures was conducted for 124 employees in early 2004.

Between September and November of 2004, surveys went to 800 employees in the 11 firms. Completed forms were received from 657 employees, for a response rate of $82 \%$. Missing data reduced the usable data set to 624 participants. I ran several $t$-tests to see if there were any major differences between respondents with no missing data and those with missing data in terms of their major demographics (age, tenure, education, and number of positions held within the firm), but I did not find significant differences. The respondents were predominantly male $(75 \%)$, highly educated (nearly $80 \%$ having four years or more of higher education), and drawn from marketing $(31.4 \%)$, research and development (R\&D) $(22.8 \%)$, finance $(20.0 \%)$, production $(13.9 \%)$, other functional areas $(8.2 \%)$, and human resource management (HRM) (3.7\%), in order of frequency. The data also came from the 11 firms in a relatively even manner $(9.4 \%$ on average and median is $8 \%$ ) ranging from 3 to $19 \%$. The sample came from five manufacturing industries: automobile (21\%), chemical (19\%), electrics (21\%), electronics $(31 \%)$, and metal/plastics (8\%). The average age of the respondents was 35 years, ranging from 22 to 55 . The average tenure within an organization was 6.4 years, ranging from 0.1 to 24 years. A major portion of the sample was composed of low- to middle-level managers (35.3\% junior managers, $31.4 \%$ assistant managers, $26.3 \%$ section/deputy managers, $6.7 \%$ managers, and $0.3 \%$ directors). As expected in a group with a strong managerial dimension and high levels of postsecondary schooling, very few participants (fewer than $10 \%$ ) belonged to a union. More than $92 \%$ worked full-time.

I sent out a separate survey to managers in human resources (HR) departments in the 11 firms to capture firm-level ILM practices. For each firm, with the help of the aforementioned contacts, I initially identified two or three senior-level managers in the HR area. I selected only managers who had worked for their company for at least eight years (i.e., during the period of 1996-2004) so that they were in a position to provide an accurate description of ILM practices before and after the Korean financial crisis that occurred at the end of 1997. I personally contacted the selected managers and invited them to participate in the survey. After I assured confidentiality of individuals and firms and guaranteed that the data would be used for the sole purpose of research, two individuals from each firm agreed to participate in the survey. The surveys sent out to these individuals were designed to obtain information on the ILMs their particular firm implemented in 2004 and 1996, respectively.

\section{Measures}

\section{Employee-Level Variables}

To establish control variables in the analysis, as well as to gather the information needed to index an employee's firm-specific human capital investment in an employment relationship with the current employer (see below), 
I asked respondents to provide information about gender, education, tenure, number of positions held within the firm, marital status, union membership, employment status (part time vs. full time), and functional area of employment. I also controlled for industry as an individual-level predictor because industry characteristics may affect the way employees engage in consummate cooperation. In addition, because of the relatively small number of firms used in the study, if I had controlled for industry as a dummy variable at the firm level, then the degrees of freedom would easily have been depleted. I measured promotion rate by the number of promotions acquired by the employees divided by the years of service and included this as a control variable.

Consummate cooperation was assessed by supervisors, who indicated the degree to which they agreed with nine statements for a specific employee. Supervisors were considered the best source of information on consummate cooperation. Because they had risen through internal job ladders and understood the job and firm context, they could effectively evaluate the quality of cooperation (Jones 1984). I developed and validated the consummate cooperation scale following the procedures recommended by experts in scale development (Spector 1992; Netemeyer, Bearden, and Sharma 2003). ${ }^{2}$ An exploratory factor analysis (EFA) suggested that the nine consummate cooperation items rated by the supervisor initially contained three distinct factors: helping with knowledge (using knowledge to help coworkers); knowledge utilization (the use of knowledge to solve work-relevant problems); and knowledge sharing (teaching or coaching coworkers). However, a confirmatory factor analysis (CFA) shown in Table 1 supported the presence of a second-order factor on which all three of the first-order factors loaded. The two-level solution yielded a good fit $\left(\chi^{2}=114.12, d f=24\right.$, $C F I=.98, G F I=.96, R M S E A=.07, S R M R=.03)$ with a coefficient alpha of .90 for the composite measure of consummate cooperation (CC). Thus, for CC, second-order factor scores used in the analysis represent a summation of all three first-order factors. A complete list of the scale items and psychometric properties of the measure is presented in Table 1.

I indexed employee's firm-specific human capital by combining two items of information about subordinates: years of tenure with the firm and number of different, distinct positions or jobs held during their years of tenure exclusively with the current employer. The assumption guiding the choice of these two measures was that an employee's firm-specific human capital investment results from both the length of time a person spends with a particular firm and the opportunity to see varied aspects of the firm and its operations from the point of view of different jobs. Lateral job mobility as well as vertical job mobility have been found to be important in internal labor market careers (Dohmen, Kriechel, and Pfann 2004). I standardized

\footnotetext{
${ }^{2}$ I generated the initial items and had their relevance judged by two leading academicians in the area of organizational citizenship behavior to ensure that the items differed enough from existing OCB scales. Next, I examined dimensionality and internal consistency and conducted a construct validity assessment with a pilot test sample of 124 Korean employees in a setting similar to that used in my study sample. Coefficient alpha from the pilot test was .89 .
} 
Table 1. Confirmatory Factor Analysis for Consummate Cooperation

\begin{tabular}{|c|c|c|c|}
\hline \multicolumn{2}{|c|}{ Scale and items } & $\begin{array}{l}\text { Standardized } \\
\text { loading } \\
\text { on the first- } \\
\text { order factor }\end{array}$ & $\begin{array}{l}\text { Standardized } \\
\text { loading } \\
\text { on the second- } \\
\text { order factor }\end{array}$ \\
\hline \multicolumn{4}{|c|}{ Consummate cooperation (Second-order factor) } \\
\hline \multicolumn{2}{|c|}{ Knowledge utilization } & - & .97 \\
\hline CC1 & $\begin{array}{l}\text { Uses his/her judgment to identify and solve } \\
\text { a work-related problem instead of leaving } \\
\text { it for others to solve }\end{array}$ & .71 & - \\
\hline CC2 & $\begin{array}{l}\text { Goes one step further to use his/her job- } \\
\text { relevant knowledge to suggest a solution } \\
\text { to a common work problem }\end{array}$ & .79 & - \\
\hline CC3 & $\begin{array}{l}\text { Uses his/her job knowledge to suggest } \\
\text { improvements in the way the work is done } \\
\text { in my work unit }\end{array}$ & .70 & - \\
\hline CC4 & $\begin{array}{l}\text { Uses his/her job knowledge to identify an } \\
\text { ineffective work procedure or practice }\end{array}$ & .77 & - \\
\hline \multicolumn{2}{|c|}{ Helping with job-relevant knowledge } & - & .88 \\
\hline CC5 & $\begin{array}{l}\text { Draws upon his/her job knowledge to } \\
\text { "cover" for somebody who is absent }\end{array}$ & .82 & - \\
\hline CC6 & $\begin{array}{l}\text { Utilizes his/her job knowledge to help } \\
\text { inexperienced coworkers }\end{array}$ & .86 & - \\
\hline \multicolumn{2}{|c|}{ Knowledge sharing } & - & .90 \\
\hline $\mathrm{CC} 7$ & $\begin{array}{l}\text { Shares his/her experience with others to } \\
\text { improve work unit performance }\end{array}$ & .88 & - \\
\hline CC8 & $\begin{array}{l}\text { Shares his/her knowledge with coworkers to } \\
\text { improve organizational efficiency }\end{array}$ & .89 & - \\
\hline CC9 & $\begin{array}{l}\text { Shares his/her skills to improve the } \\
\text { performance of others }\end{array}$ & .74 & - \\
\hline
\end{tabular}

Notes: All estimates were significant at $p<.001$. Fit statistics for the measurement model of 21 indicators for nine constructs: $\chi^{2}=114.12, d f=24 ; C F I=.98 ; S R M R=.03 ; R M S E A=.05$.

each of the measures into z-scores and summed the two normal deviates to provide the index. These two measures correlated at $r=.616$.

I included several control variables to rule out potential alternative hypotheses. Because the rate of increase of cooperation may decrease as a result of the aging process, I controlled for both age and age squared. Also possible is that the generation of employees who entered the employment relationship before the Asian financial crisis could engage in consummate cooperation as a response to experiencing two extreme-strong and weak-attributes of ILMs operated by the employer. I included a five-item job interdependence measure by Pearce and Gregersen (1991) because the extent to which a job requires coordination with others rather than an employee's discretionary cooperative effort could be related to the level of cooperation. Illustrative items of job interdependence included "I frequently must coordinate my efforts with others"; "My own performance is dependent on receiving accurate information from others"; and "My work requires me to consult with others fairly frequently." I used job satisfaction as a control variable because satisfaction in the workplace may explain consummate cooperation. I used a 
six-item scale (Tsui, Egan, and O'Reilly 1992) in which respondents answered the following illustrative question items: "Considering everything, how satisfied are you with your current job situation?" "How satisfied are you with the person who supervises you-your organizational superior?" "How satisfied are you with your relations with others in the organization with whom you work-your coworkers or peers?" For both job interdependence and job satisfaction, I used seven-point Likert scales (strongly disagree to strongly agree). Finally, I controlled for the number of ratees by a supervisor because the number of subordinates that a supervisor was asked to rate may affect the consummate cooperation of a specific employee.

\section{Firm-Level Variables}

I included firm size as one of the firm-level control variables. The firm size is the $\log$ of the number of employees based on the total number of employees obtained from a corporate database provided by the Korea Chamber of Commerce and Industry. HR managers from each company provided information on the degree to which ILMs were in operation in their firms. The ILM information came from surveys that were separately distributed to HR managers in the 11 firms. A set of questions addressed specific ILM features used in the year 1996 and 2004 at each firm. To develop these measures, I modified the Pfeffer and Cohen (1984) approach regarding the following aspects: seniority-based rewards (Doeringer and Piore 1971; Gerhart and Rynes 2003; Dulebohn and Werling 2007), long-term employment (Doeringer and Piore 1971; Gerhart and Rynes 2003), on-the-job training (Doeringer and Piore 1971; Pfeffer and Cohen 1984; Gerhart and Rynes 2003), and promotion from within (Althauser and Kalleberg 1981). The HR managers provided information about these aspects of the ILM.

With regard to the four aforementioned ILM features, the survey included questions from two general categories: Scale Type 1, the extent to which a specific ILM feature is used at the firm level applies universally to all workers within the firm (e.g., number of days of corporate training offered at the entry level), and Scale Type 2, in which the use of a specific ILM policy at the firm level applies to a specific position (e.g., average yearly corporate training offered). In the case of the latter, the HR managers identified ILM features used for each of the six positions: junior manager, assistant managers, section manager, deputy manager, manager, and director. On the basis of the reported percentage of each of these positions out of the total employees of a firm, I calculated the weighted average for each ILM feature. For example, if the HR managers reported the existence of a certain ILM feature for the six positions-"yes $(=1)$, yes $(=1)$, yes $(=1)$, no $(=0)$, no $(=1)$, and yes $(=1)$," respectively-and the percentage of those positions out of total employment in a firm was $40 \%, 30 \%, 20 \%, 7.5 \%, 1.5 \%$, and $1 \%$, respectively, then I applied these weights appropriately to produce an overall percentage of workforce covered under the particular ILM feature: $(1 \times .40+1$ $\mathrm{x} .30+1 \times .20+0 \times .075+1 \times .015+1 \times .01=92.5 \%)$. The weighted average indicates the percentage of the workforce to which a particular ILM feature 
applies. Even though I am conceptually interested in firm-level variation in ILM features for a job (i.e., white-collar managers only), I asked about the ILM features for six different positions in order to 1) increase the level of accuracy of ILM features reported by HR managers, and 2) characterize the firm-level ILM features based on the distribution of the positions within the firm. I did not believe the equal weight approach was a reasonable representation of firm-level ILM features.

I measured on-the-job training by five items: 1) days of corporate training at entry (number of days); 2) average yearly corporate training offered (number of times); 3) average yearly online training offered; 4) use of crossfunctional training $(1=$ yes, $0=$ no $)$; and 5$)$ official mentoring $(1=$ yes, $0=$ no). I measured seniority-based rewards by four items: whether the firm 1) offered a pay bonus as a function of tenure (specifically, 10-year, 15-year, and 20-year pay bonuses); 2) offered a pay differential within each position based on seniority $(1=$ yes, $0=$ no $)$; 3 ) offered a benefit privilege based on seniority for each position $(1=$ yes, $0=$ no $)$; and 4$)$ had a requirement of tenure or recommended number of years in one position to be promoted to the next position $(1=$ yes, $0=$ no). Internal promotion was measured by four items: 1) the average percentage of vacancies filled internally for each position; 2) the average rate of promotion for each position to the next position; 3) whether the firm had a policy of internal advertising when there was a vacant position $(1=$ yes, $0=$ no $)$; and 4$)$ whether the firm had a practice of filling a position with members from the same business group $(1=$ yes, $0=$ no). Long-term employment was measured by asking the HR manager to rate 1) whether layoffs were done for a specific position in the last eight years $(1=$ yes, $0=$ no $)$; 2$)$ whether an early retirement program was used for a specific position in the last eight years $(1=$ yes, $0=$ no); and finally 3 ) the percentage of workforce reduction by either layoffs or an early retirement program in the last eight years. Since the units associated with these questionnaires were all different, I standardized the scores from each practice and then took the average for the global index of ILM practices.

\section{Data Analysis}

I assessed the construct validity of the key variable, employee consummate cooperation, by conducting both exploratory and confirmatory factor analysis. I also assessed the reliability of the measures. I used hierarchical linear modeling (HLM) (Raudenbush and Bryk 2002) for hypothesis testing because the effects of ILMs at the firm level on consummate cooperation would be manifested at the organizational level, and individual characteristics such as firm-specific human capital also affect employee cooperation at the individual level. All the variables were grand-mean centered except dummy variables (Hofmann and Gavin 1998). 


\section{Results}

\section{External Market Pressures and Firm Choices about ILMs}

Table 2 provides the average of firm-level ILMs used in the 11 firms included in this study as reported by two HR managers from each company. Because I aggregated the ILMs across two HR managers from each firm, I calculated the interclass correlation (ICC) (2), which indicates the reliability of the aggregated means. The ICC (2) for 2004 ILMs and ILM change (between 2004 and 1996), which I used in the HLM analyses, ranged from .63 to .97. These values are within the acceptable level for data aggregation (McGraw and Wong 1996; Bliese 2000); they are also significantly larger than the corresponding ICC (1) values, confirming that employing more than one HR manager could improve the measurement reliability level (Wright et al. 2001).

There were some interesting patterns in the way ILMs were used in these 11 firms. First, except for two particular practices (average yearly online training offered and official mentoring), from 1996 to 2004 the firms in this study decreased the strengths of ILMs by an average of $26 \% .^{3}$ Because online training was not readily available and because the concept of official mentoring was adopted into the Korean economy in the late '90s, the increase of these two practices is understandable. Of the 14 ILM practices that the firms reduced, paired sample $t$-tests suggested that the reduced use of the 11 practices was significant. Although firms appeared to decrease seniority-based compensation, the reduction of three practices associated with senioritybased compensation was insignificant. Second, the standard deviations of these practices among the 11 firms were much larger in 2004 than in 1996. On average, these firms were characterized by stronger and more uniform ILMs in 1996. After 1996, they differed in their desertion of ILMs, creating larger variance in ILM operation in 2004. In other words, firms characterized as having strong ILMs in 2004 retained the ILMs that were in place in 1996, while those firms low in their 2004 use of the ILMs had deserted ILMs since 1996. The data suggest that firms overall reduced the use of ILMs, yet the heterogeneity among these firms in retaining ILMs had significantly increased. This serves as empirical evidence for Proposition 1.

\section{Descriptive Statistics}

Table 3 provides means, standard deviations, reliabilities, and intercorrelations for the measures and variables used in the study. These data pertain to the individual level of analysis. At the individual level, consummate cooperation was positively and significantly related to the use of ILM practices: $(r=$

\footnotetext{
${ }^{3}$ The percentage reduction was calculated in the following manner. First, it was calculated for 14 practices except OJT3 (use of online training) and OJT5 (use of official mentoring). For example, the reduction rate for OJT1 was $\left(\mathrm{OJT1}_{1996}-\mathrm{OJT1}_{2004}\right) / \mathrm{OJT}_{1996}$, which was $23 \%$. For LTE1R 3R, since these are reverse-coded items (i.e., short-term employment), I calculated the percentage of the workforce that was not exposed to these practices $(=100 \%$ - percentage of the workforce that was under the influence of LTER). Then I took the average reduction rate of these practices by adding the reduction rates for all of them and dividing the total by 14 .
} 


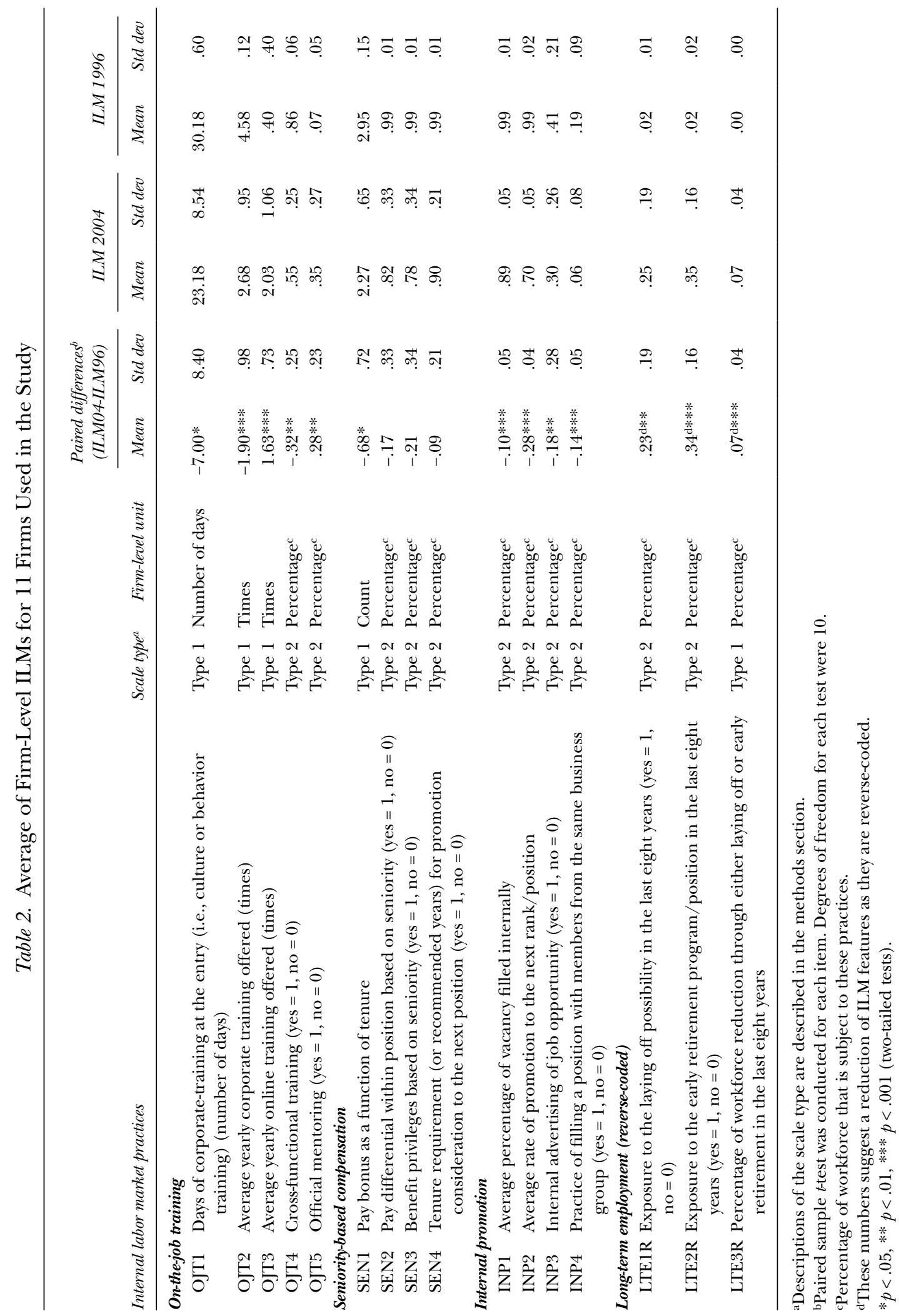




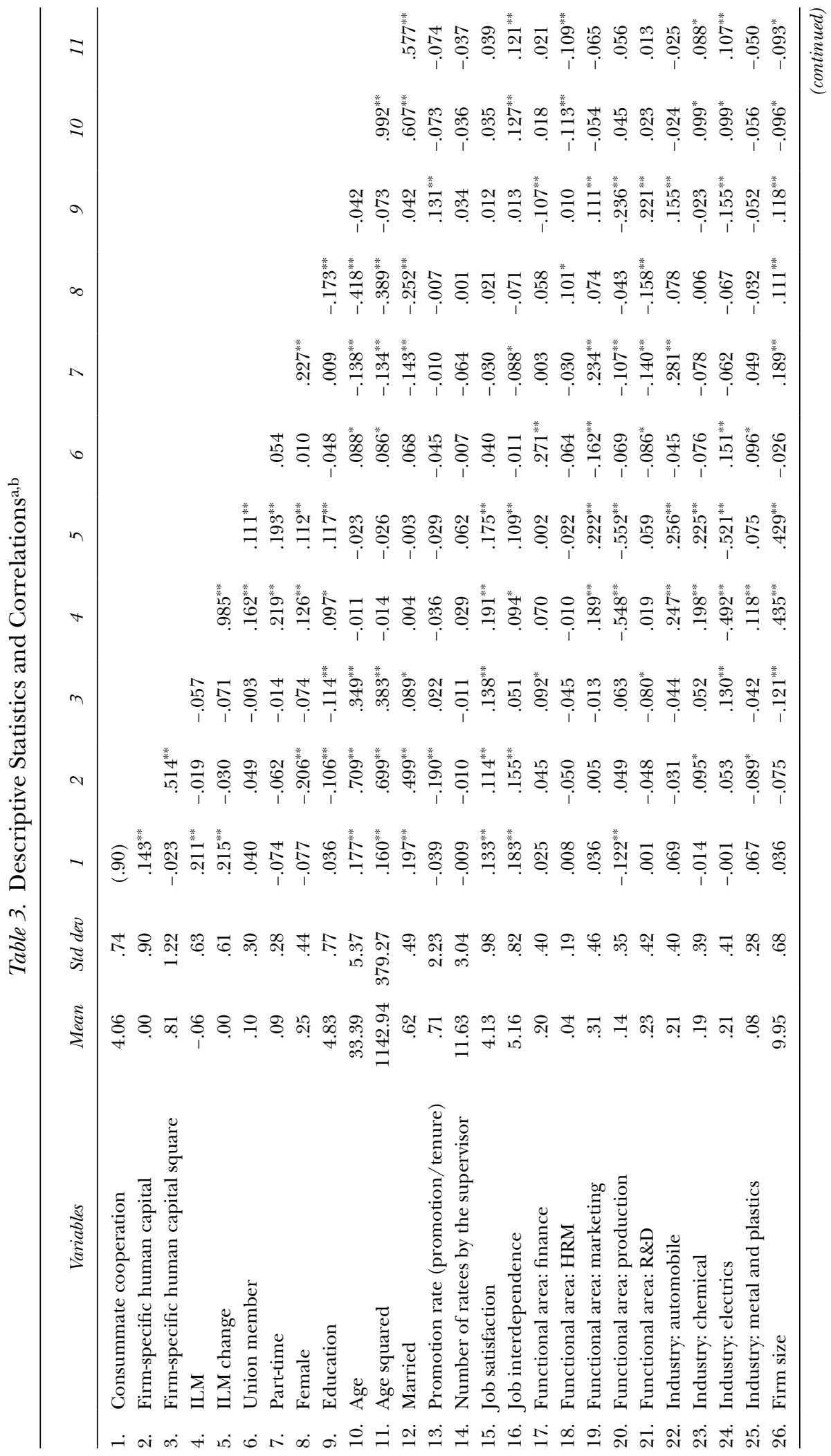




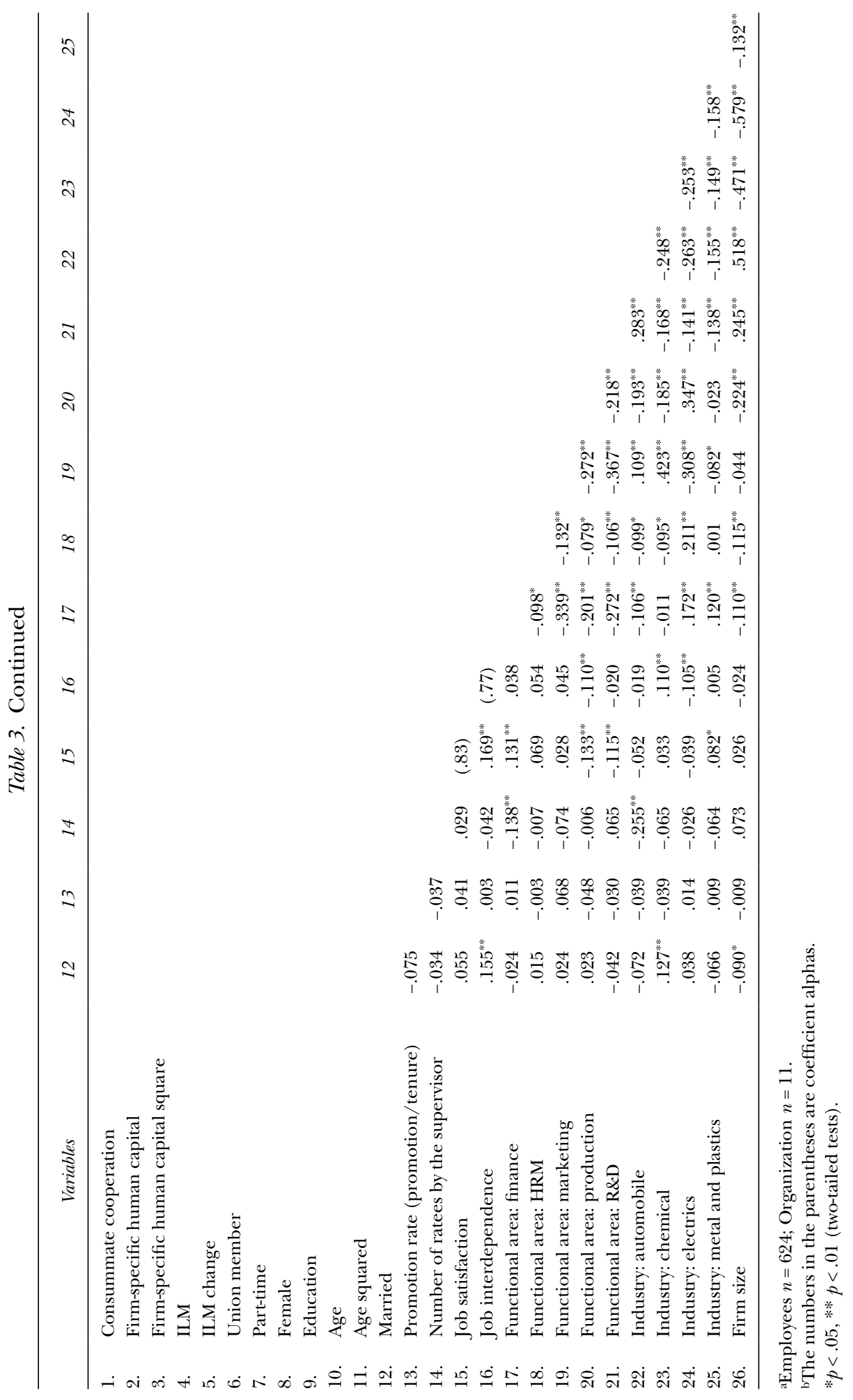


$.21, p<.01)$. To check for multicollinearity, I used two measures to assess pair-wise and multiple-variable collinearity: tolerance and the variance inflation factor (VIF). Tolerance values ranged from .42 to .97, and the VIF ranged from 1.06 to 2.42. Small tolerance values less than .10 and VIF measures higher than 10.0 are considered to be indicators of problems with multicollinearity. The values in the current study did not approach those levels, suggesting that the data did not pose any multicollinearity problems.

\section{HLM Hypothesis Testing}

Following the recommendation by Bryk and Raudenbush (1992), to test Hypotheses 1 to 3, I ran a two-level HLM analysis where the outcome variable was consummate cooperation.

\section{Null Model}

Table 4 summarizes the results from the HLM. I hypothesized that significant variance in consummate cooperation would be explained at both the organizational and individual levels. To test these hypotheses, I first had to ascertain that significant organizational variance in consummate cooperation existed. Thus, I first estimated a null model in which consummate cooperation was a linear function of three parameters: the grand mean of the population of individuals, a random effect due to individuals, and a random effect due to organizations. I found significant between-organization variability: $\left(\tau_{00}=.11, p<.001\right)$. The ICC indicated that $18 \%$ of the variance in consummate cooperation was between organizations and about $72 \%$ within organizations.

Model 1 in Table 4 lists HLM results in which consummate cooperation is regressed on all the level-1 control variables. About $14 \%$ of the withinorganization variance of consummate cooperation was explained by the set of variables. The difference between ordinary least squares (OLS) regression and what is presented in Model 1 is that, in addition to the fixed effects (represented as regression coefficients) as in OLS regression, the HLM measured the random effects of the intercepts and slopes in the model. The random effects are listed in parentheses. In Model 2, I entered employee firm-specific human capital and also its squared term in the HLM equation along with the level-1 control variables. As a result, compared with Model 1, Model 2 gained a $4 \%$ additional increase in terms of the within-organization $R$-square. The squared term of firm-specific human capital was significant: $(\hat{\gamma}=-.09, p<.01)$. The sign associated with it was negative, confirming that the relationship between firm-specific skills and consummate cooperation is nonlinear and resembles an inverted-U shape, supporting Hypothesis 1.

In Model 3, in addition to the level-1 predictors in Model 2, I entered a firm-level control: firm size. Compared with Model 2, adding the firm size variable resulted in an additional $24 \%$ of the between-organization $R$-square. In Model 4, in addition to firm size, I included ILMs in the HLM equation. 


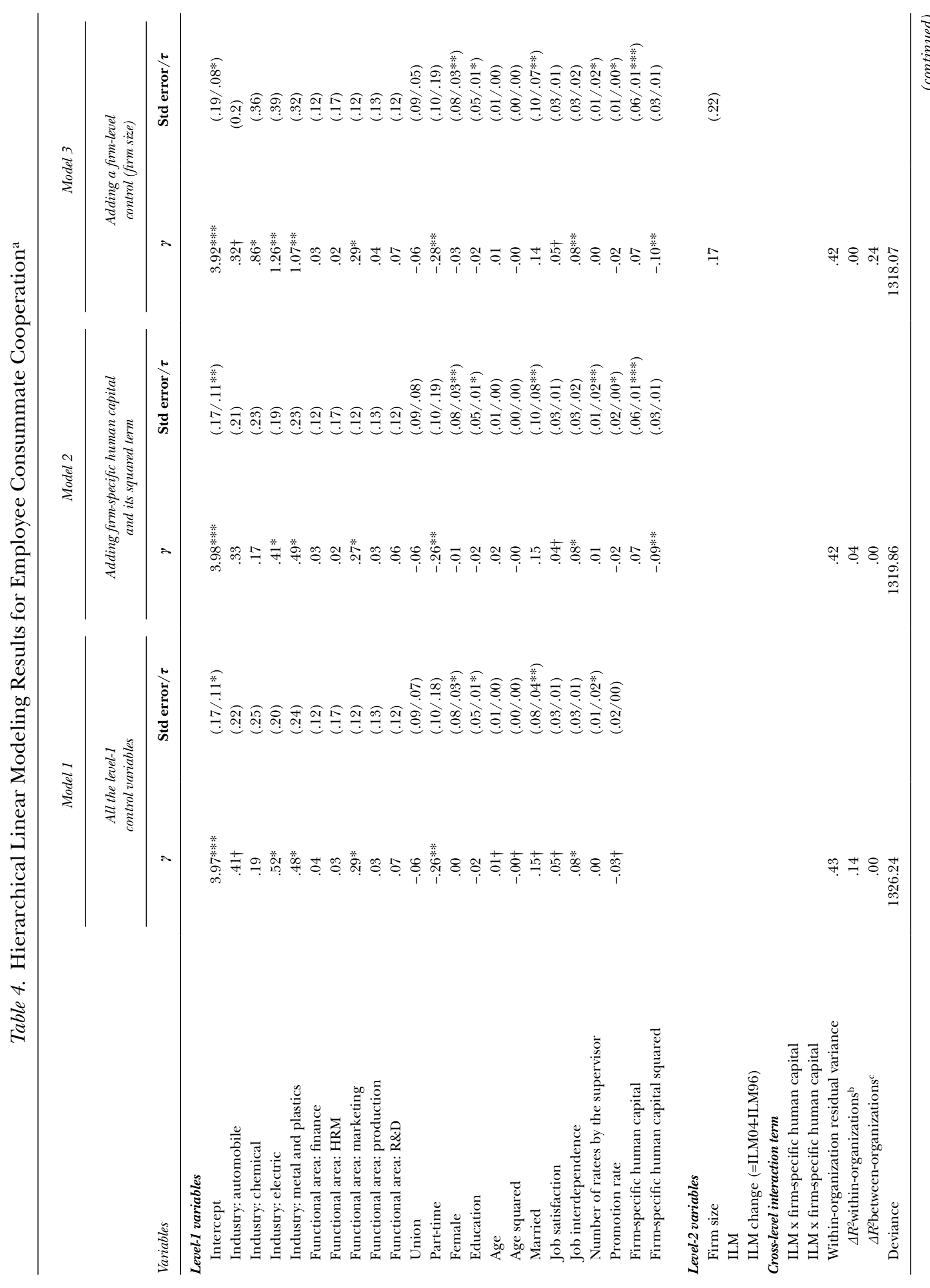




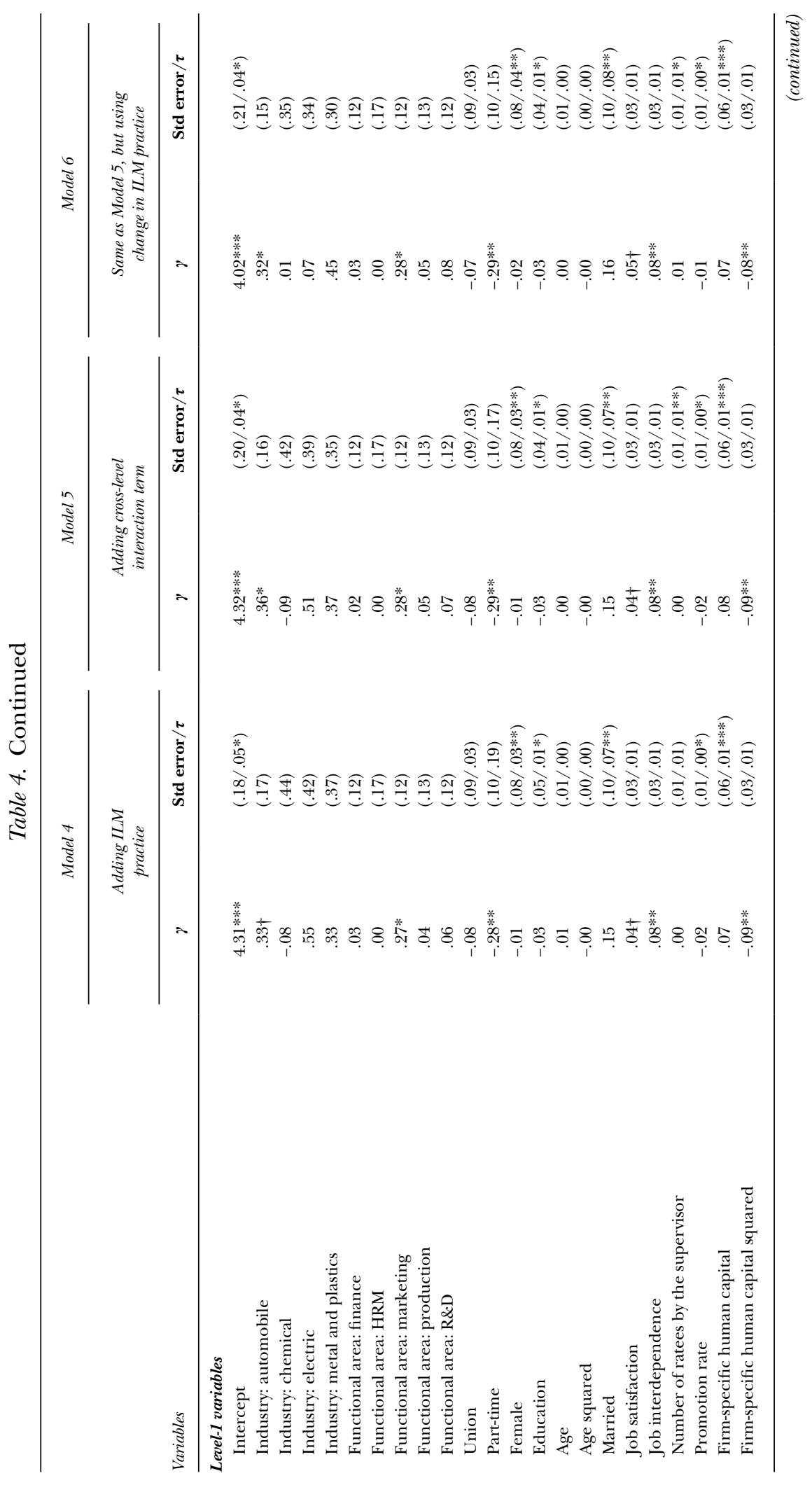




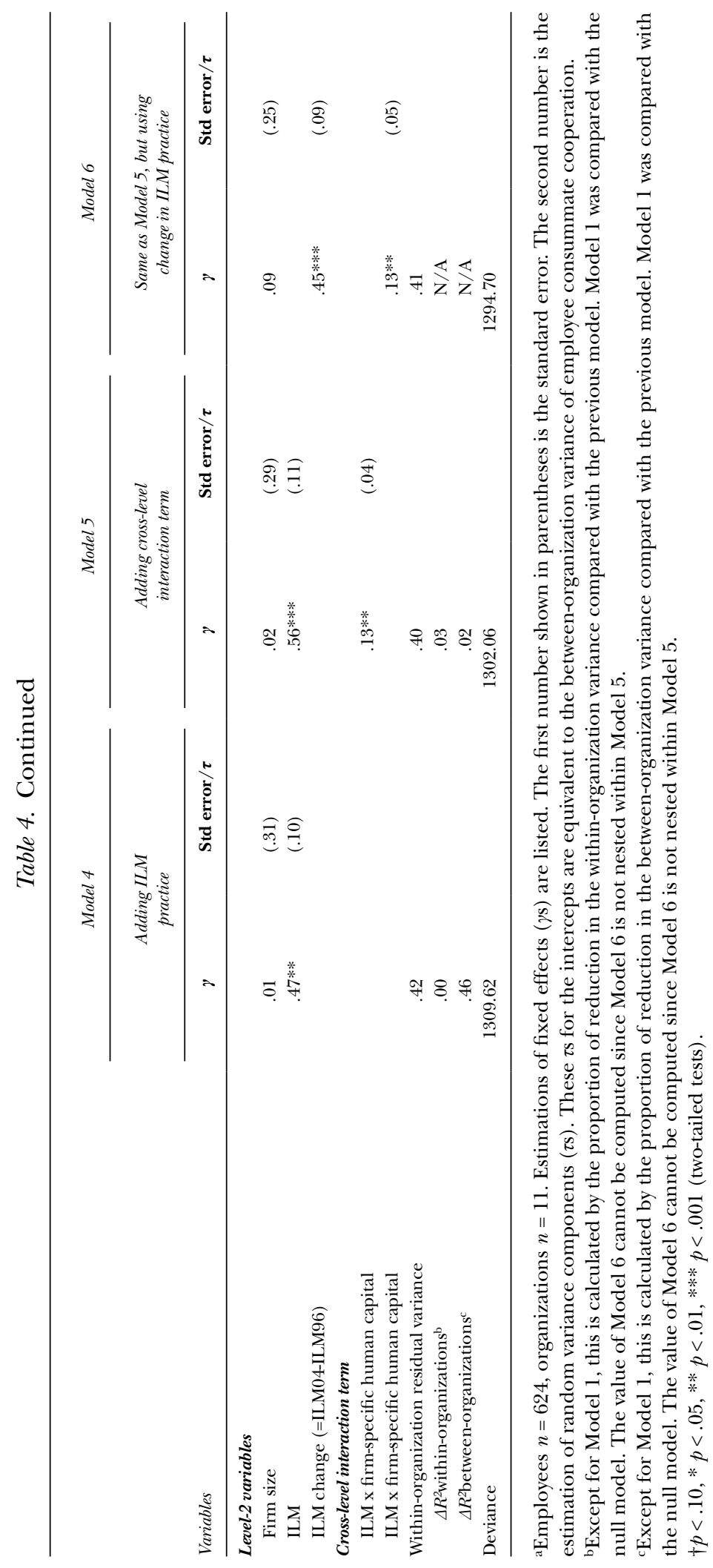


Regressing the intercept from level-1 predictors on the objective ILM properties at the firm level, in addition to firm size (level-2 control variable), amounts to testing Hypothesis 2, which posited a significant association between objective ILM properties and consummate cooperation at the organizational level. In this instance, objective ILM properties were significantly related to consummate cooperation: $(\hat{\gamma}=.47, p<.01)$. Compared with Model 2, the objective ILM properties explained $46 \%$ additional betweenfirm variance.

In Model 5, in addition to all the variables included in Model 4, I included the cross-level interaction term between ILMs and employee's firm-specific human capital. If the coefficient of the interaction term as well as the negative coefficient of the firm-specific human capital squared term are significant simultaneously, they serve as evidence that the point of shirking that happens in organizations with weak ILM attributes $\left(k_{w}^{*}\right)$ significantly differs from that in organizations with strong ILM attributes $\left(k_{s}^{*}\right)$. Rejecting the null hypothesis (HO: $k_{w}{ }^{*}=k_{s}^{*}$ ) can serve as evidence to support Hypothesis 3. As was hypothesized, the interaction term was significantly related with consummate cooperation in the expected direction $(\hat{\gamma}=.13, p<.01)$ as well as the squared term of firm-specific human capital $(\hat{\gamma}=-.09, p<.01)$. Thus, Hypothesis 3 is supported. Compared with Model 4, an additional 3\% of the within-firm variance and an additional $2 \%$ of between-firm variance is explained by the interaction term.

In Model 6, I entered all the variables found in Model 5 into the HLM equation, but instead of ILMs measured in 2004, I entered the change in the use of ILMs between 1996 and 2004 to explain the level of consummate cooperation measured in 2004. I assumed that firms make the first move in choosing the degree to which they rely on ILMs, and the Asian financial crisis that occurred in 1997 could serve as an empirical background in which varying choices by the firm could be captured. Possibly, the changes in ILMs (=ILM2004 - ILM1996) may reflect a better approximation of the firm's choices in varying degrees of ILM practices. The results using the change in ILMs were generally the same or slightly better than those that measured ILMs only in 2004.

\section{A Graphical Depiction of the Significant Relationships}

Using the data from Model 5 in Table 4, I depicted the nature of the significant interaction effect found in the analyses. Figure 2 shows how the association between employee firm-specific human capital and consummate cooperation varies across three different levels (one standard deviation below the mean, the mean, and one standard deviation above the mean) of ILMs.

As the graphical depiction suggests (Figure 2), the empirical findings resulted in an almost plateau relationship between firm-specific human capital and consummate cooperation in organizations with stronger ILMs and an inverted curvilinear U-shape in organizations with weaker ILMs. The peak point of consummate cooperation-where perfunctory cooperation 
Figure 2. Graphical Depiction of the Significant Interaction Effects between the Strength of Firm's ILM and Employee Firm-Specific Human Capital on Consummate Cooperation

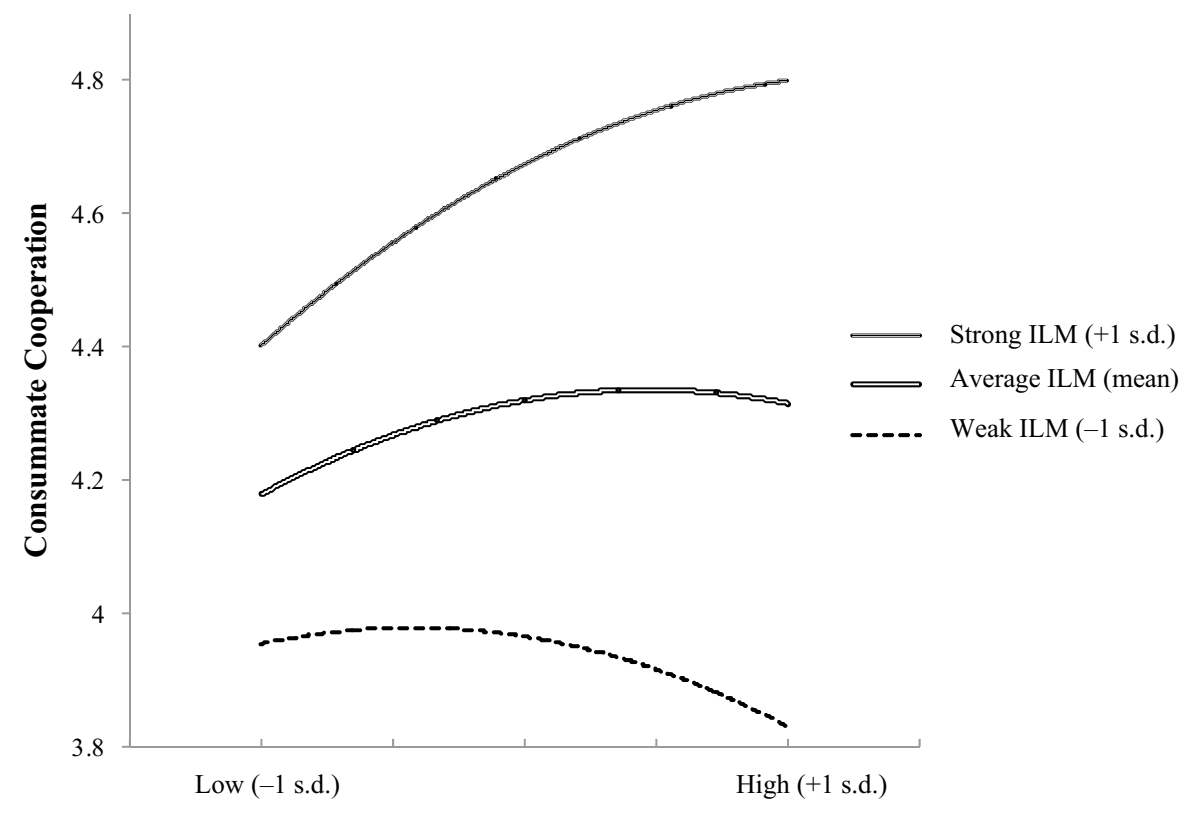

Firm-Specific Human Capital

starts to occur-is at a strikingly lower level of firm-specific human capital when the firm relies less on ILMs rather than more. When ILMs are pervasive for an organization, the point of perfunctory cooperation is slightly beyond the range of firm-specific human capital skills on the graph, suggesting that perfunctory cooperation occurs at a point beyond one standard deviation above the mean.

\section{Additional Analyses}

The current index measure of firm-specific human capital captures both 1) positions acquired within the firm and 2) tenure with the current employer. Given the nature of the index, the unit of the index could be difficult to interpret, potentially limiting the practical implications of the study. For this reason, instead of using the index to capture firm-specific human capital, I ran additional HLM analyses using only tenure with the current employer. Unlike the index, the original unit of tenure is interpretable. That is, the unit is a year, and the average and the standard deviation of tenure are 6.56 years and 5.18 years, respectively.

I used standardized values of tenure (with a mean of zero and one for standard deviation) for the HLM analyses because centering is required not only for HLM analysis (Raudenbush and Bryk 2002) but also for a graphical depiction of estimated equations (Aiken and West 1991). In addition, as I 
Figure 3. Depicting the Estimated Equations and Points of Inflections When Tenure Is Used for Firm-Specific Human Capital

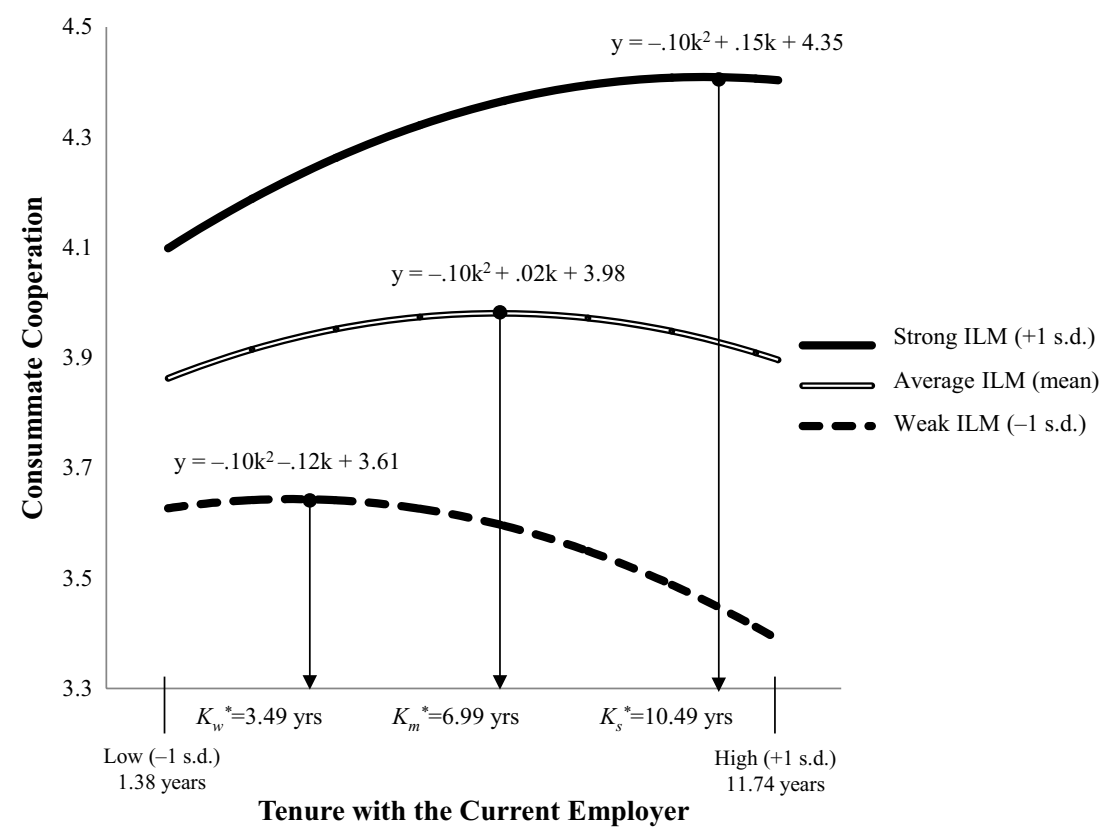

used standardized values for the index, the use of standardized values for tenure allows for an easy comparison of the results. The points of inflection at three different levels of ILMs can be still calculated back to the original unit, which is a year. The estimated equations and the estimated points of inflection at different levels of ILMs using HLM analyses are summarized in Table 5 and also graphically depicted in Figure 3.

As seen in Table 5 and Figure 3, on average, the point of inflection where perfunctory cooperation occurs is when employees reach approximately seven years of tenure. This time frame is slightly above the average tenure (6.56 years) in the sample. The points where perfunctory cooperation occurs at a weak level of ILMs (-1 SD) and a strong level of ILMs (+1 SD) are 3.49 and 10.49 years, respectively. That is, in contrast to firms with weak ILMs, firms with strong ILMs under external market pressure can delay perfunctory cooperation by seven years $(=10.49-3.49)$.

\section{Discussion}

Given the increasing external market pressures that firms face, the major goal of the current study was to 1) investigate the extent to which firms desert or retain ILM practices and 2) evaluate the merits of retaining ILMs through an examination of employee cooperation. I leveraged the context of the Asian financial crisis to test whether firms varied in their retention of ILMs, and whether in turn, this led to differences in the cooperative behavior of employees. 
Table 5. Estimating the Points of Inflections When Tenure Is Used for Firm-Specific Human Capital

\begin{tabular}{|c|c|c|}
\hline & The estimated equations & $\begin{array}{l}\text { The estimated point of } \\
\text { inflection }\left(k^{*} \text { or } K^{* 1}\right)^{a}\end{array}$ \\
\hline $\begin{array}{l}\text { Firms with weak ILMs (one } \\
\text { standard deviation below the } \\
\text { mean) }\end{array}$ & $\begin{array}{l}\text { Estimated equation: } \\
y=-.1 k^{2}-.1184 k+3.61 \\
\text { Differential equation: } \\
\frac{d y}{d k}=-2 k-.1184\end{array}$ & $\begin{array}{l}k_{w}{ }^{*} \text { is the value of } \mathrm{k} \text { that makes } \\
\begin{array}{l}\frac{d y}{d k}=0 \\
\therefore k_{w}^{*}=.758, \text { or } \\
\therefore K_{w}^{*}=6.56+5.18 \cdot(.758) \\
\quad=10.49 \text { (years) }\end{array}\end{array}$ \\
\hline Firms with average ILMs (mean) & $\begin{array}{l}\text { Estimated equation: } \\
y=-.1 k^{2}+0.166 k+3.98 \\
\text { Differential equation: } \\
\frac{d y}{d k}=-2 k+.0166\end{array}$ & $\begin{array}{l}k_{m}{ }^{*} \text { is the value of } \mathrm{k} \text { that makes } \\
\frac{d y}{d k}=0 \\
\begin{aligned} \therefore k_{m} & =.083, \text { or } \\
\therefore K_{w}^{*} & =6.56+5.18 \cdot(.083) \\
& =6.99 \text { (years) }\end{aligned}\end{array}$ \\
\hline $\begin{array}{l}\text { Firms with strong ILMs (one } \\
\text { standard deviation above the } \\
\text { mean) }\end{array}$ & $\begin{array}{l}\text { Estimated equation: } \\
y=-.1 k^{2}+0.1516 k+4.35 \\
\text { Differential equation: } \\
\frac{d y}{d k}=-2 k+.1516\end{array}$ & $\begin{array}{l}k_{s}^{*} \text { is the value of } \mathrm{k} \text { that makes } \\
\frac{d y}{d k}=0 \\
\therefore k_{s}^{*}=-.592, \text { or } \\
\therefore K_{w}^{*}=6.56+5.18 \cdot(-.592) \\
=3.49 \text { (years) }\end{array}$ \\
\hline
\end{tabular}

$\mathrm{a} k *$ is the normalized value (average $=0$; standard deviation $=1$ ) and $K^{*}$ is tenure in its original unit (average $=6.56$ years; standard deviation $=5.18$ years). Thus, the unit of $k *$ is a standard deviation, and the unit of $K^{*}$ is a year.

The preceding analysis indicates, first, that the 11 large South Korean firms studied, which quite uniformly used strong ILMs before the Asian financial crisis (Lee 1989; Chang 2003; Kim and Kim 2003), largely deserted ILM practices thereafter, suggesting that many have reevaluated the value of these practices. Although seniority-based compensation was relatively unaffected, the use of the other three dimensions of ILMs (on-the-job training, internal promotion, and long-term employment) clearly eroded soon after the Asian financial crisis (1997-2004). Interestingly, however, these firms showed considerable variation in their reduction of ILM practices. While the average use of ILM practices by these firms clearly fell after the crisis, the standard deviation in use also grew substantially. Overall, these firms, which employed ILMs in a uniform fashion before the crisis, subsequently showed considerable variation in their ILM practices.

With the increase in external market pressures, the general value that firms place on firm-specific human capital is likely to fall because it is costly to monitor its use and firms may need to focus more on short-term gains. This may lead to a rise in agency problems associated with firm-specific human capital. Given the decreased value of firm-specific human capital, there may be less need to monitor its use within firms. And with the lack of monitoring, employees may be less prone to utilize acquired firm-specific human capital. In addition, a sense of social and psychological breach among employees with a high level of firm-specific human capital is likely to 
arise if employers signal that this type of intellectual capital is not valued. I have argued that without proper incentives and monitoring, job incumbents may show a tendency to decrease marginal consummate cooperation as their firm-specific human capital increases. The results of the HLM analysis showed inverted-U relationship between firm-specific human capital and consummate cooperation. Furthermore, the results indicate that external market pressures created a situation in which employees switched their mode of cooperation from consummate to perfunctory as they acquired additional firm-specific human capital.

The current study highlights two attractive features of ILMs. First, the results show that at any given level of firm-specific human capital, the level of employee consummate cooperation in firms with stronger ILMs was higher than in firms with weaker ILMs. This supports the notion that ILMs are well-suited to encourage employee consummate cooperation, as proponents of transaction cost economics have argued (Williamson et al. 1975). Accordingly, ILM practices are apt to promote consummate cooperation, which can be neither easily measured nor appropriately rewarded in the external labor market. Though this has been a central assumption in ILM theory, to my knowledge it has not previously been empirically investigated or substantiated.

Another attractive feature of ILMs in the face of external market pressures is their ability to delay employee perfunctory cooperation even though ILMs do not completely eliminate it. I anticipated that the point at which employees stopped increasing their cooperation would be delayed when an employer relied relatively more on ILMs. That perfunctory cooperation comes at a higher level of firm-specific human capital in organizations with stronger ILMs than in those with weaker ILMs is confirmed by the significance of the interaction term between ILMs and firm-specific human capital in the presence of the significant and negatively squared term of firm-specific human capital.

I view the contribution of this study to the ILM literature as having a number of dimensions. The study documents and measures the extent to which firms deserted or retained ILM practices when faced with the shock of an economic crisis. Although there have been qualitative descriptions of the disintegration of ILMs, few have quantified these changes. In addition, I am not aware of any multilevel research testing the effect of internal labor markets on employee cooperation, even though the construct "consummate cooperation" is a key variable in Williamson et al.'s (1975) analysis. The current study is the first to empirically test whether the strength of a firm's ILM is reliably associated with consummate cooperation at the firm and the individual employee level.

The findings of this study also address current debates regarding the relative benefits of ILMs. The curvilinear relationship between firm-specific human capital and consummate cooperation in firms at various levels of ILM strength has two main implications. First, advocating the use of ILM practices solely on the basis of firm-specific human capital advantages may 
not be appropriate because it does not take into account the way in which information impactedness and agency issues allow employees with higher levels of firm-specific human capital to decrease their effort. In the past, when this curvilinear relationship and the divergent interests of employers and employees were not considered, the advantages of ILMs may have been overstated.

Second, the study also implies that internal labor market practices still remain an attractive option for employers as long as consummate cooperation is an essential ingredient for employee success and survival. The results found a significant association between ILM practices and consummate cooperation. In addition, a strong ILM employed by a firm was associated with a delayed point of perfunctory cooperation.

The current study also provides additional understanding of how workers react to varying employer choices in retaining ILM practices in response to macroeconomic environmental changes. Before the Asian financial crisis, large Korean firms relied on internal labor markets to a much greater extent than did U.S. firms (Cho 2005; Jung and Cheon 2006). Consistent with the findings of other studies, this study indicates that overall employment stability in Korea has deteriorated since the economic crisis, and job security has been significantly reduced in many large firms. According to Jung and Cheon (2006), white-collar workers in Korea who once enjoyed the benefits of stable employment are at the front lines of the dramatic change.

One must note the limitations of inference and generalization of the results reported here. I examined only 11 firms and have no means of ascertaining whether these firms are representative of the South Korean national economy, let alone the global one. The results may also be occupationspecific. They reflect the characteristics of white-collar managers but may not go beyond that specific occupational group. Therefore, future research may need to replicate this study with other occupational groups. Industry characteristics peculiar to the Korean setting might also have contributed to the findings of this study. Caution against overgeneralizing is warranted. Finally, I cannot presume to address the effects of ILM attributes in a different societal culture-for example, one with less emphasis on and respect for hierarchy or collective values. The sample surveyed was part of the Korean economy-a specific cultural and economic situation. Korea, whose national culture is characterized by high levels of collectivism and high power distance, has a cultural setting that may be consonant with strong ILM attributes. The virtues of ILM practices may be less evident in other national cultures. Separating the effects of culture from the mechanism of ILMs is an important task for future studies. It would be especially meaningful to replicate the study in a Western cultural setting to determine how a different culture might affect the relationships investigated in this article.

In conclusion, this study reveals that although the preference for ILMs has decreased among firms in the face of external market pressures, firms understandably vary greatly in choosing ILMs as a viable option under these pressures. The study also reveals that, among employees, agency issues have 
arisen that are associated with firm-specific human capital in terms of withholding consummate cooperation and/or sensing breaches of social/ psychological contracts. Most important, however, the efficiency of ILMs in obtaining employee consummate cooperation and delaying (rather than preventing) employee perfunctory cooperation in the face of external market pressure held true.

By highlighting the significant relationships between ILMs and consummate cooperation in an economy hit by external market pressures, the current study does not intend to conclude that the lack of overall employee consummate cooperation in firms with lower ILM attributes automatically puts those firms at a disadvantage. The conclusion depends on the degree to which a firm depends on employee cooperation.

What my study suggests is that the efficiency of ILMs in obtaining employee consummate cooperation holds true in an economy for which such logic is most challenged by external market pressures. However, if one interprets the efficiency of internal labor markets from the perspective of generating more firm profit than employee cooperation, this article does not provide any helpful answers. I am not sure whether consummate cooperation would be the best ingredient for firm performance in the globalization of the labor market. But to the extent that cooperation based on site-specific knowledge remains important, that it must be acquired in a particular context over a long period, and that uninhibited and unrestrained application of such knowledge rests on faith in a fair and open-ended exchange, ILMs remain an option that firms may choose even under globalization.

\section{References}

Aaronson, Daniel, and Daniel G. Sullivan. 1998. The decline of job security in the 1990s: Displacement, anxiety and their effect on wage growth. Economic Perspectives 1998(Q1): 17-43.

Abraham, Katharine G. 1990. Restructuring the employment relationship: The growth of market-mediated work arrangements. In Katharine G. Abraham and Robert McKersie (Eds.), New Developments in the Labor Market: Toward a New Institutional Paradigm, pp. 85118. Cambridge, MA: MIT Press.

Abraham, Katharine G., and Susan K. Taylor. 1996. Firms' use of outside contractors: Theory and evidence. Journal of Labor Economics 14: 394-424.

Adler, Paul S., and Bryan Borys. 1996. Two types of bureaucracy: Enabling and coercive. Administrative Science Quarterly 41(1): 61.

Aiken, Leona S., and Stephen G. West. 1991. Multiple Regression: Testing and Interpreting Interactions. Newbury Park, CA: Sage Publications.

Alchian, Armen A., and Harold Demsetz. 1972. Production, information costs, and economic organization. American Economic Review 62: 777-95.

Althauser, Robert P., and Arne L. Kalleberg. 1981. Firms, occupations, and the structure of labor markets: A conceptual analysis. In Ivar E. Berg (Ed.), Sociological Perspectives on Labor Markets, pp. 119-49. New York: Academic Press.

Barney, Jay B., and William Hesterly. 1999. Organizational economics: Understanding the relationship between organizations and economic analysis. In Stewart Clegg and Cynthia Hardy (Eds.), Studying Organization, pp. 109-41. Thousand Oaks, CA: Sage Publications. 
Baron, James N., Alison Davis-Blake, and William T. Bielby. 1986. The structure of opportunity: How promotion ladders vary within and among organizations. Administrative Science Quarterly 31(2): 248-73.

Batt, Rosemary. 1996. From bureacracy to enterprise? In Paul Osterman (Ed.), Broken Ladders, pp. 55-80. New York: Oxford University Press.

Bliese, Paul D. 2000. Within-group agreement, non-independence, and reliability: Implication for data aggregation and analysis. In Katherine J. Klein and Steve W. J. Kozlowski (Eds.), Multilevel Theory, Research, and Methods in Organizations, pp. 349-81. San Francisco: Jossey-Bass.

Bryk, Anthony S., and Stephen W. Raudenush. 1992. Hierarchical linear models. Newbury Park, CA: Sage Publications.

Cappelli, Peter. 1995. Rethinking employment. British Journal of Industrial Relations 33(4): 563-602.

- 1999. The New Deal at Work: Managing the Market-Driven Workforce. Boston: Harvard Business Press.

Chang, Sea-Jin. 2003. Financial Crisis and Transformation of Korean Business Groups: The Rise and Fall of Chaebols. New York: Cambridge University Press.

Chauvin, Keith W. 1994. Firm-specific wage growth and changes in the labor market for managers. Managerial and Decision Economics 15(1): 21-37.

Cho, Joonmo. 2005. Human resource management, corporate governance structure and corporate performance in Korea: A comparative analysis of Japan, US, and Korea. Japan and the World Economy 17: 417-30.

Davis-Blake, Alison, and Brian Uzzi. 1993. Determinants of employment externalization: A study of temporary workers and independent contractors. Administrative Science Quarterly 38(2): 195-223.

Doeringer, Peter B., and Michael J. Piore. 1971. Internal Labor Markets and Manpower Analysis. Lexington, MA: D. C. Heath.

Dohmen, Thomas J., Ben Kriechel, and Gerard A. Pfann. 2004. Monkey bars and ladders: The importance of lateral and vertical job mobility in internal labor market careers. Journal of Population Economics 17: 193-228.

Dulebohn, James H., and Stephen E. Werling. 2007. Compensation research past, present, and future. Human Resource Management Review 17(2): 191-207.

Evans, Ramstad. 2007. Pulling rank gets harder at one Korean company. Wall Street Journal, August 20.

Fairris, David. 2004. Internal labor markets and worker quits. Industrial Relations 43(3): 57394.

Friedman, Thomas L. 2005. The World Is Flat: A Brief History of the Twenty-First Century. New York: Farrar, Straus, and Giroux.

Gerhart, Barry, and Sara L. Rynes. 2003. Compensation: Theory, Evidence, and Strategic Implications. Thousand Oaks, CA: Sage Publications.

Gordon, David M. 1996. Fat and Mean: The Corporate Squeeze of Working Americans and the Myth of Managerial "Downsizing." New York: Kessler Books/Free Press.

Hofmann, David A., and Mark B. Gavin. 1998. Centering decisions in hierarchical linear models: Implications for research in organizations. Journal of Management 25(5): 623-41.

Horan, K. 2004. Where are the jobs? BusinessWeek, March 22, 36-37.

Jacoby, Sanford M. 1984. The development of internal labor markets in American manufacturing firms. In Paul Osterman (Ed.), Internal Labor Markets, pp. 23-69. Cambridge, MA: MIT Press.

- 2004. Employing Bureacracy: Managers, Unions, and the Tranformation of Work in the 20th Century, Rev. ed. Mahwah, NJ: Lawrence Erlbaum.

Jensen, Michael C., and William H. Meckling. 1976. Theory of the firm: Managerial behavior, agency costs, and ownership structure. Journal of Financial Economics 3(4): 305-60.

Jones, Gareth R. 1984. Task visibility, free riding, and shirking: Explaining the effect of structure and technology on employee behavior. Academy of Management Review 9(4): 684-95.

Jung, Eehwan, and Byung-you. Cheon. 2006. Economic crisis and changes in employment relations in Japan and Korea. Asian Survey 46(3): 457-76. 
Jwa, Sung-Hee. 2002. The Evolution of Large Corporations in Korea. Cheltenham, UK: Edward Elgar.

Kanter, Rosabeth M. 1984. Variations in managerial career structures in high-technology firms: The impact of organizational chracteristics on internal labor market patterns. In Paul Osterman (Ed.), Internal Labor Markets, pp. 109-31. Cambridge, MA: MIT Press.

-1993. Men and Women of the Corporation. New York: Basic Books.

Kim, Dong-one, and Seongsu Kim. 2003. Globalization, financial crisis, and industrial relations: The case of South Korea. Industrial Relations 42(3): 341-67.

Kuwahara, Yasuo. 2010. Employment relations in Japan. In Greg J. Bamber, Russell D. Lansbury, and Nick Wailes (Eds.), International and Comparative Employment Relations: Globalisation and Change, 5th ed., pp. 249-74. Thousand Oaks, CA: Sage Publications.

Lee, Hak Chong. 1989. Managerial characteristics of Korean firms. In Kae H. Chung and Hak Chong Lee (Eds.), Korean Managerial Dynamics, pp. 147-62. New York: Praeger

Malcomson, James M. 1984. Work incentives, hiearchy, and internal labor markets. Journal of Political Economy 92: 486-507.

McGraw, Kenneth O., and S. P. Wong. 1996. Forming inferences about some intraclass correlation coefficients. Psychological Methods 1(1): 30-46.

Netemeyer, Richard G., William O. Bearden, and Subhash Sharma. 2003. Scaling Procedures: Issues and Applications. Thousand Oaks, CA: Sage Publications.

Niehoff, Brian P., and Robert H. Moorman. 1993. Justice as a mediator of the relationship between methods of monitoring and organizational citizenship behavior. Academy of Management Journal 36(3): 527-56.

Organ, Dennis W., Philip M. Podsakoff, and Scott B. MacKenzie. 2006. Organizational Citizenship Behavior: Its Nature, Antecedents, and Consequences. Thousand Oaks, CA: Sage Publications.

Osterman, Paul. 1987. Choice of employment systems in internal labor markets. Industrial Relations 26(1): 46-67.

- 2000. Work reorgnization in an era of restructuring. Industrial and Labor Relations Review 53(2): 179-96.

- 2008. The Truth about Middle Managers: Who They Are, How They Work, Why They Matter. Boston: Harvard Business Press.

Osterman, Paul, and Diane M. Burton. 2004. Ports and ladders: The nature and relevance of internal labor markets in a changing world. In Pamela Tolbert and Rosemary Batt (Eds.), Oxford Handbook on Work and Organization, pp. 425-45. Oxford: Oxford University Press.

Ouchi, William G. 1980. Markets, bureaucracies, and clans. Administrative Science Quarterly 25: $129-41$.

Park, Young-Bum, and Chris Legget. 2010. Employment relations in Korea. In Greg J. Bamber, Russell D. Lansbury, and Nick Wailes (Eds.), International and Comparative Employment Relations: Globalisation and Change, 5th ed., pp. 275-93. Thousand Oaks, CA: Sage Publications.

Pearce, Jone L., and Hal B. Gregersen. 1991. Task interdependence and extrarole behavior: A test of the mediating effects of felt responsibility. Journal of Applied Psychology 76(6): $838-44$.

Pfeffer, Jeffrey. 2010. Lay off the layoffs. Newsweek, February 5.

Pfeffer, Jeffrey, and Yinon Cohen. 1984. Determinants of internal labor markets in organizations. Administrative Science Quarterly 29(4): 550-72.

Raudenbush, Stephen W., and Anthony S. Bryk. 2002. Hierarchical Linear Models: Applications and Data Analysis Methods, 2nd edition. Thousand Oaks: CA: Sage Publications.

Robinson, Sandra L. 1996. Trust and breach of the psychological contract. Administrative Science Quarterly 41 (4): 574-99.

Robinson, Sandra L., Matthew S. Kraatz, and Denise M. Rousseau. 1994. Changing obligations and the psychological contract: A longitudinal study. Academy of Management Journal $37(1): 137-52$.

Rousseau, Denise M., and J. M. Parks. 1992. The contracts of individuals and organizations. In Barry M. Staw and Larry L. Cummings (Eds.), Research in Organizational Behavior, Vol. 15, pp. 1-43. Greenwich, CT: JAI Press. 
Royal, Carol, and Robert P. Althauser. 2003. The labor markets of knowledge workers. Work and Occupations 30(2): 214-33.

Ryan, Paul. 1984. Job training, employment practices, and the large enterprise: The case of costly transferable skills. In Paul Osterman (Ed.), Internal Labor Markets. Cambridge, MA: MIT Press.

Schmidt, Stefanie R. 1999. Long-run trends in workers' beliefs about their own job security: Evidence from the General Social Survey. Journal of Labor Economics 17(4): s127-41.

Segal, Lewis M., and Daniel G. Sullivan. 1997. The growth of temporary services work. Journal of Economic Perspectives 11(2): 117-36.

Sheets, Robert G., and Yuan Ting. 1988. Determinants of employee-termination benefits in organizations. Administrative Science Quarterly 33(4): 607-24.

Sinaiko, H. Wallace, and Richard W. Brislin. 1973. Evaluating language translations: Experiments on three assessment methods. Journal of Applied Psychology 57 (3): 328-34.

Smith, Vicki. 1997. New forms of work organization. Annual Review of Sociology 23: 315-39.

Spector, Paul E. 1992. Summated Rating Scale Construction: An Introduction. Newbury Park, CA: Sage Publications.

Tsui, Anne S., Terri D. Egan, and Charles A. O’Reilly, III. 1992. Being different: Relational demography and organization attachment. Administrative Science Quarterly 37(4): 549-79.

Vroom, Victor H. 1964. Work and Motivation. New York: Wiley.

Williamson, Oliver E., Michael L. Wachter, and Jeffrey E. Harris. 1975. Understanding the employment relation: The analysis of idiosyncratic exchange. Bell Journal of Economics 6(1): 250-78.

Williamson, Oliver E. 1985. The Economic Institutions of Capitalism. New York: The Free Press.

Wright, Patrick M., Timothy M. Gardner, Lisa M. Moynihan, Hyeon Jeong Park, Barry Gerhart, and John E. Delery. 2001. Measurement error in research on human resources and firm performance: Additional data and suggestions for future research. Personnel Psychology 54(4): 875-901. 